\title{
PReS-FINAL-2170: Work disability in adult patients with juvenile idiopathic arthritis (JIA)
}

\author{
C Goldenstein-Schainberg*, J Gordo, R Krieger, LE Paula, N Aikawa, \\ on behalf of Reumatologia, Faculdade de Medicina, Universidade de Sao Paulo, Sao Paulo, Brazil \\ From 20th Pediatric Rheumatology European Society (PReS) Congress \\ Ljubljana, Slovenia. 25-29 September 2013
}

\section{Introduction}

Approximately 20\% JIA patients enters adulthood with clinically active disease and disabled, therefore work condition may be affected.

\section{Objectives}

To assess the prevalence of work disability among adult patients with JIA regularly attending a tertiary rheumatology center and to determine possible associated risk factors.

\section{Methods}

This was a cross-sectional study that enrolled 43 JIA patients according to 2004 revised ILAR criteria. A questionnaire was developed in order to evaluate working status and labor activity: occupation, current/previous work, employment status and withdrawal rate were actively searched. Demographic data, JIA characteristics, clinical activity (DAS28 $>2.6$ ), therapeutic intervention, comorbidities, physical activity, sedentarism (WHO definitions), functional class (1991 ACR criteria), HAQ and SF-36 were recorded. The prevalence of work disability was calculated using $95 \%$ confidence interval, and compared to all parameters; qualitative variables were analyzed using tests of association (chi-square test) and quantitative variables by Mann-Whitney or student test.

\section{Results}

Patients' mean age was $29+7.4$ yrs (range 19-41) with mean JIA duration $=17.2+12.3 \mathrm{yrs}$ (range $3-33) ; 63 \%$ were males and $37 \%$ females. JIA subtypes were $64 \%$ polyarticular, $11 \%$ oligoarticular, $9 \%$ systemic, $9 \%$ ERA,
$2 \%$ extended oligoarticular, $2 \%$ psoriatic arthritis; $7 \%$ had uveitis. Serum RF was positive in $21 \%$ and ANA in $21 \%$. The majority $(72 \%, \mathrm{n}=31)$ of JIA patients were employed, whereas $28 \%(\mathrm{n}=12)$ were currently not working. In the latter group, 83\% (10/12) were retired due to JIA related disability. Further analysis comparing those currently working vs. Those not working revealed similar age $(25,3$ yrs vs.29,5 yrs, $\mathrm{p}=0,09)$. Although not significantly, most patients currently working had Poly onset JIA ( 22 vs. $6 \mathrm{p}=0,37$ ), higher frequencies of good education level $>12$ yrs of school (31 vs.9, $\mathrm{p}=0,38$ ), functional class I $(\mathrm{p}=0,96)$, practiced regular physical activity ( 9 vs. $0, \mathrm{p}=0,89$ ), were singles ( 26 vs. $8, \mathrm{p}=$ $0,15)$. Both groups had comparable HAQ and DAS 28 scores $(0,62$ vs. $0.59, \mathrm{p}=0,47$ and 2,51 vs.2,07, $\mathrm{p}=0,64)$ and similar arthroplasty rate ( 8 vs. $4, \mathrm{p}=0,427)$. Frequencies of hypertension ( 3 vs. $1, \mathrm{p}=0,999$ ), dyslipidemia ( 1 vs. $1, \mathrm{p}=0,125)$, diabetes ( 1 vs. $0 \mathrm{p}=0,999)$, depression ( 1 vs. $0, \mathrm{p}=0,999)$ and smokers ( 3 vs. $1, \mathrm{p}=$ $0,99)$ were alike in both groups. Remarkably, employed patients had higher SF 36 mental health component (84.0 vs. $70.42, \mathrm{P}=0.01$ ).

\section{Conclusion}

High prevalence of almost $1 / 3$ work disability and of retirement due to disease related incapacity remain major problems for adult JIA individuals. We also identified worse mental health in employed patients indicating that further research is needed, in addition to intense affirmative disability actions in order to remove possible disabling barriers and to adapt restrictive environments for these patients. Moreover, enhanced strategies and policy for inclusion of JIA patients in the job market is urged.

\footnotetext{
Reumatologia, Faculdade de Medicna, Universidade de Sao Paulo, Sao Paulo,
} Brazil 


\section{Disclosure of interest}

None declared.

Published: 5 December 2013

doi:10.1186/1546-0096-11-S2-P182

Cite this article as: Goldenstein-Schainberg et al: PReS-FINAL-2170: Work

disability in adult patients with juvenile idiopathic arthritis (JIA). Pediatric Rheumatology 2013 11(Suppl 2):P182.

Submit your next manuscript to BioMed Central and take full advantage of:

- Convenient online submission

- Thorough peer review

- No space constraints or color figure charges

- Immediate publication on acceptance

- Inclusion in PubMed, CAS, Scopus and Google Scholar

- Research which is freely available for redistribution

Submit your manuscript at www.biomedcentral.com/submit
Ciomed Central 